\title{
Investigation of Organizational and Regional Perceptions on the Changes in Construction Projects
}

\author{
Osman ÍLTER ${ }^{1}$ \\ Tahir ÇELIK ${ }^{2}$
}

\begin{abstract}
One of the most common concern in construction projects is changes during execution. Changes can increase the cost and duration of the construction project hereby, can lead to conflict between the parties involved in construction projects. Causes of the changes may differ depending on the organizations and regions characteristics. The aim of this study is to investigate the impact of organizational and regional characteristics on key change factors. In this regard, top risky change factors were identified with respect to contractors, consultants, and owners located in North Cyprus, Turkey, and the U.S.A. The research findings showed that the most risky change factors differed in accordance with the characteristics of organizations and regions. It was concluded that "Errors/Inadequacies in Contract Drawing" was the riskiest factor according to contractors while "Low price due to high competition" was noted to be the riskiest change causes with respect to consultants and owners. If different countries were compared, "Inconsistency between different design disciplines" was identified as the top risky change factor according to the respondents in the U.S.A. located organizations, but "Low contract price" was designated as the top risky change factor according to the respondents in North Cyprus and Turkey. In addition, key measures were suggested to mitigate changes in accordance with organizational and regional characteristics.
\end{abstract}

Keywords: Changes in construction, cost-time over-run, claims, mitigation measures.

\section{INTRODUCTION}

Changes during the construction process are one of the most common problems in construction projects. Ming et al. [1], stated that changes are one of the most common distress in construction. Ibbs et al. [2], were defined "Any addition, deletion, or any other revision to project goals and scope of work are considered to change, whether they increase or decrease the project cost or schedule". Almost all construction projects are subject to various changes during the execution process. Changes made during execution trigger many problems in the construction project.

\footnotetext{
Note:

- This paper was received on July 24, 2019 and accepted for publication by the Editorial Board on April 23, 2020.

- Discussions on this paper will be accepted by January 31, 2022.

- https://doi.org/10.18400/tekderg.595995

1 Eastern Mediterranean University, Department of Civil Engineering, Cyprus - osman.ilter@cc.emu.edu.tr https://orcid.org/0000-0002-3270-3523

2 Cyprus International University, Department of Civil Engineering, Cyprus - tcelik@ciu.edu.tr https://orcid.org/0000-0002-2943-0640
} 
Increasing project cost and time are called as the most important problems caused by the changes in construction projects. Aness et al [3], indicated that the average cost and time overrun due to change orders is between 11 and $15 \%$ of the original contract value and between 10 and $20 \%$ of the original project duration in large projects in Egypt. Problems created by changes are serious aside from the quality, budget and time are considered as the most important parameters of a project. Moselhi et al. [4], emphasized that changes are one of the major issues that cause poor project performance, such as degradation of productivity, delay [5], and cost overruns [6]. As a result, it is almost become impossible to complete construction projects within the targeted budget and time frame, so the projects are completed in failures. Such problems are often seen in Northern Cyprus and Turkey. Arditi et al. [7], stated that frequent change orders are the most important source of delay in public projects in Turkey. Kazaz et al. [8], emphasized that "design and material changes" is the main delay reason on construction projects carried out in Turkey. Most cases in courts related to the construction sector are related to disputes between the parties as a result of changes [9]. The owner, project manager, and contractor as main stakeholders exhibit different approaches with respect to the requirements and evaluation of changes. The contractor is usually in a struggle to claim additional payment and time as a consequence of any changing case in the project $[10,11]$ however, clients are often not volunteer to meet the contactors 'claims, and therefore the projects could not be terminated at the targeted budget and time, so the parties suffer various losses [11].

\section{RESEARCH BACKGROUND}

\subsection{Change Causes and Effects}

Many researchers have investigated and analysed the causes and effects of change factors in construction projects on the basis of different regions and project characteristics. For this reason, the causes and effects of changes have been examined extensively with a comprehensive literature survey. The most significant change causes according to the different regions and organizational characteristics were presented as high factor findings as follows.

Assaf and Hejji [12], were stated that change orders are the most common cause of delay in the Saudi Arabia construction sector according to consultant, contractor, and owners. Kazaz et al [8], were emphasized that design and material changes are becoming the most significant delay causes in the Turkish construction sector based on contractor's views. Kaming et al. [13], have demonstrated that design changes and material costs increased due to inflation is becoming the most significant factors that cause time and cost overruns in the Indonesia construction sector according to project manager's evaluation. Zaneldin [14] was designated that change orders are the most frequent claim causes in construction projects implemented in Dubai and Abu Dhabi. Ijaola and Iyagba [15], and Oladapo [16], were determined the type of causes, effects, and sources as well as benefits and remedial actions of change orders for construction projects in Nigeria and Oman. It was concluded that additional work and modification to design were the most common change order factors both in Nigeria and Oman and project cost and time overruns were as around 79 and 68 percent as a result of a change order in Nigeria. Hassanein and Nemr [17], were demonstrated that $54 \%$ of causes of claims in the Egyptian construction sector have been resulted due to change orders. Besides, change orders can be allowed in $57 \%$ of the projects in Egypt due to poor documentation practices by the contractor's team were identified [17]. Enshassi et al. [18], were identified 64 causes of change order through literature review to demonstrate the most 
common and important type of change orders with respect to different party's perceptions operating in the Gaza strip. "Lack of construction material and equipment" and "change in design" were emphasized to be the most significant change causes according to all parties in Gaza Strip. Stare [19], was clarified that $90 \%$ of project changes are the reason for project delay and cost overrun in construction projects carried out in Slovenia. Arain and Pheng [11], were specified that changes in plan or scope, unforeseen problems, and defective problems were the most frequent were most significant causes of change orders for institutional buildings in Singapore [20], and their effect on project cost was determined [20]. Wu et al. [21], were explored 90 metropolitan public work projects in Taiwan to identify causes and impact of change orders on project cost and duration under two main evaluation dimensions as technical and administrative. It was concluded that "changed orders owing to legislative or policy changes" were designated as the most significant causes of a change order in highway construction projects carried out in Taiwan.

Akinsola et al. [22], were identified the types and quantified factors influencing change order on the total cost of change and the average rate of change in construction projects. Lu and Issa [23], were demonstrated that the most frequent and most costly changes were often related to design changes and design errors. The time-cost relationship of the building projects in Turkey was investigated by taking into consideration the changes in exchange rate and the number of working days due to climatic effects [24]. Ahbab et al. [25] were concluded that design changes and poor project management and supervision are the main causes that severely affect time management in large transportation projects financed by the Asian Development Bank. Project variables have been investigated with hypothesis testing to predict whether the project is impacted [26] and loss of labor efficiency were quantified by linear regression equation as $40.05 \%$ due to change orders [27]. Wambeke et al.[28], were examined the causes of changes in construction projects in order to evaluate the effect on the starting time and duration of tasks as well as the number and type of people impacted as a result of changes. Moselhi et al. [4], were explored 117 projects implemented in the U.S.A. and Canada to examine productivity loss of labor due to change orders by developing the Neural Network Model. Lee et al. [29], were analyzed the amount and number of loss events due to change orders that occurred in apartment projects in South Korea by using the Loss Distribution Approach method. Diekman and Nelson, [30] were indicated that the most common causes of claims were resulted by change orders. Bröchner and Badenfelt [31], were investigated 16 contractual relationships in Sweden to identify change reasons and explored their frequencies according to contract type and contractual incentives respectively. Bakr [32] was identified as the most common cause of changes in the Jordan construction industry by exploring the historical data of change cases that occurred in construction projects. Ezgi et al. [33] were investigated the effect of tendering procedure and contract type on the contract price by analysing 19.546 tender procedures of construction work data between the years 2007 and 2017 in Turkey. The likelihood of disagreement due to changes was emphasized to be high in lump sum contracted compared to the unit price contracted construction projects in Turkey. In addition, authors were revealed that most of contract price of the works between 2007 and 2017 were below the threshold value.

At the end of the comprehensive literature review, it has been realized that the key change causes vary depending on the organizational, regional and project characteristics since organizations and regions have their own particular characteristics, construction law, cultures, economies, and construction technologies. Hence, this paper aims to examine the top risky change factors for a lump sum and design-bid-build contracted building construction projects according to the construction organizations located in North Cyprus-Turkey and the U.S.A. Furthermore, this 
study aimed to suggest mitigation measures in accordance with organizational and regional characteristics.

\subsection{Measures to Reduce Changes}

In this study, suggestions were referred to reduce changes hereby, the measures suggested to mitigation changes were monitored in the literature and presented as follow.

Hassanein and Nemr [17], were clarified that formation of standard form of contract conditions along the same line of FIDIC contracts for international project can be effective solution to proper change order claims management in the Egyptian construction industry. Besides, awareness of good contract document of site team will be beneficial for contractor organizations to be able to manage change order claims. Aness et al. [3], were stated that "adding clause regulating change order procedures to have clear procedures for handling the change orders in construction contracts" and "negotiation of change order cases by knowledgeable person" were the most effective change management process to reduce the negative impact of change in Egypt construction industry. Improvement on contractual procedure, common understanding amongst professionals when interpreting customer's requirements and application of new technology in design phase as Building Information Modelling (BIM) were designated as the most effective potential methods to reduce frequency of change on educational building projects in Nigeria [34]. Ijaola and Iyagba [15], were noted that, assigned of specialized quantity surveyor and project manager and development of standard document from beginning to completion of projects were the most effective change order remedies in construction projects in Nigeria and Oman. Taylor et al. [35], were stated that "front end planning" could be beneficial to mitigate change orders due to owner-induced enhancement, contract item overrun and contract omissions in highway construction projects. Dumont et al. [36], were emphasized that design and construction cost are reduced by $20 \%$ and total design and construction schedule is reduced by as much as $39 \%$ by front end planning (pre project planning) process in industrial based projects. Zaneldin [14], was referred that "reasonable time for design"," efficient quality control techniques", "clearly written contracts"," good contract awareness", "establishment of risk sharing philosophy" and "proper job records" were the most effective claim preventive factors for United Arab Emirates construction projects. Chan and Kumaraswamy [37], were indicated that "effective site management and data communication", "good site investigation" and "value management techniques to minimize client initiated changes" the most effective factors to minimize time overruns in Hong Kong construction projects.

At the end of the comprehensive literature review, it has been realized that, various mitigation measures have been suggested to be able to control changes and to reduce its negative effects on projects according to the regional and project characteristics. At this point, the changes need to be managed by different methods in accordance with the organization and regional characteristic. Applying the most appropriate mitigation measure according to the factor influencing the change is required in order to get the most benefits in this regard, this study aimed to suggest the key mitigation measures in accordance with the characteristics of organizations and regions. 


\section{RESEARCH METHOD}

\subsection{Determination the Change Factors in Construction Projects}

In the first phase of the study, the causes of changes in construction projects were identified based on the validity of the literature. Factors that are commonly accepted as change causes in literature were listed. At the end of a comprehensive literature survey, it was targeted to include all kinds of change factors representing almost all kinds of events encountered in construction projects. Furthermore, the change causes have been categorized in order to provide a better orientation. In this regard, change factors were listed whether to represent events originated due to technical, administrative, construction process, persons and external issues. In this regard, change factors were listed whether to represent events originated due to technical, administrative, construction process, persons and external issues. Hereby, a total of 25 different factors that influence changes were identified through 33 different research sources (See in Table 1).

Table 1 - Change Factors and References

\begin{tabular}{|c|c|c|}
\hline & Change Factors & References \\
\hline \multirow{8}{*}{ 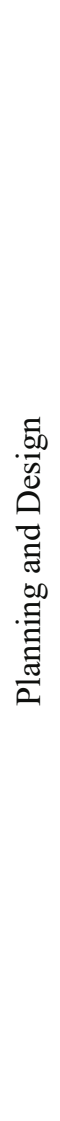 } & Errors in Contract Drawings & $\begin{array}{l}\text { Hsieh et al. [38], Memon et al. [39], } \\
\text { Motawa, I.A.[40], Lee et al. [29], Love et } \\
\text { al. [41], Chen, [42], Sun and Meng [43], } \\
\text { Enshassi [18] }\end{array}$ \\
\hline & $\begin{array}{l}\text { Inconsistencies between different } \\
\text { Designs }\end{array}$ & $\begin{array}{l}\text { Sun and Meng [43], Chan and } \\
\text { Kumaraswamy [37],Hsieh et al. [38],Wu } \\
\text { et al. [21], }\end{array}$ \\
\hline & $\begin{array}{l}\text { Errors and Inadequacy in } \\
\text { Specification }\end{array}$ & $\begin{array}{l}\text { Hsieh e al. [38], Sun and Meng [43],Wu et } \\
\text { al. [21],Assaf and Hejji [12], Enshassi } \\
\text { [18], Kazaz et al. [8], }\end{array}$ \\
\hline & Conflict among contract documents & $\begin{array}{l}\text { Hsieh e al. [38], Odeh and Battaineh, [44], } \\
\text { Lo et al. [45], Zaneldin [14], Arain and } \\
\text { Pheng [20], Motawa, I.A. [40], Enshassi } \\
\text { [18] }\end{array}$ \\
\hline & Use of Poor design software & Assaf and Hejji [12] \\
\hline & Constructability Ignored & $\begin{array}{l}\text { Motawa, I.A. [40],Rosenfeld,[46],Assaf } \\
\text { and Hejji [12] }\end{array}$ \\
\hline & $\begin{array}{l}\text { Error in Cost Estimating and } \\
\text { budgeting }\end{array}$ & $\begin{array}{l}\text { Hsieh e al. [38], Sun and Meng [43], } \\
\text { Zaneldin [14], Kazaz et al. [8], Sha'ar et al. } \\
\text { [47], Mansfield et al. [48] }\end{array}$ \\
\hline & $\begin{array}{l}\text { Unrealistic imposed contract } \\
\text { duration }\end{array}$ & $\begin{array}{l}\text { Sun and Meng [43], Zaneldin } \\
\text { [14],Memon et al. [39], Odeh and } \\
\text { Battaineh [44], Doloi et al. [49], Sha'ar et } \\
\text { al.[47] }\end{array}$ \\
\hline
\end{tabular}


Table 1 - Change Factors and References (continue)

\begin{tabular}{|c|c|c|}
\hline \multirow{6}{*}{ 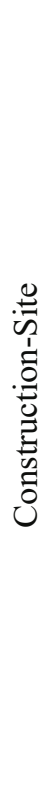 } & $\begin{array}{l}\text { Inadequate site investigation in pre- } \\
\text { construction }\end{array}$ & $\begin{array}{l}\text { Mohamad et al.[50],Wu et al.[21], Assaf } \\
\text { and Hejji [12], Kazaz et al. [8] }\end{array}$ \\
\hline & $\begin{array}{l}\text { Uncertainties / problems of } \\
\text { Subsurface }\end{array}$ & $\begin{array}{l}\text { Hsieh e al.[38], Lee et al. [29],Mohamad } \\
\text { et al. [50],Wu et al.[21], Assaf et al. [48], } \\
\text { Odeh and Battaineh [44], Zaneldin, [14] }\end{array}$ \\
\hline & $\begin{array}{l}\text { Provision of additional shop } \\
\text { drawings }\end{array}$ & $\begin{array}{l}\text { Yap et al. [52],Cox et al.[53],Cox and } \\
\text { Hamilton, [54], Odeh and Battaineh [44], } \\
\text { Assaf and Hejji [12], Enhassi et al.[55] }\end{array}$ \\
\hline & Errors in execution & $\begin{array}{l}\text { Sun and Meng [43], Zaneldin [14] ,Kazaz } \\
\text { et al. [8], Sha'ar et al. [47], Assaf and Hejji } \\
\text { [12] }\end{array}$ \\
\hline & $\begin{array}{l}\text { Material / Equipment / Manpower } \\
\text { shortage }\end{array}$ & $\begin{array}{l}\text { Memon et al. [39],Yap et al.[52], O’Brien } \\
\text { [10], Kazaz et al.[8], Arditi et al. [7], Arain } \\
\text { and Pheng[20], Enshassi [18], Arain et al } \\
\text { [56], }\end{array}$ \\
\hline & Additions / Omissions of work & $\begin{array}{l}\text { Mohamad et al.[50], Ijaola and Iyagba } \\
{[15]}\end{array}$ \\
\hline \multirow{3}{*}{$\frac{0}{2}$} & $\begin{array}{l}\text { Lack of Experience of Project } \\
\text { Participants }\end{array}$ & $\begin{array}{l}\text { Motawa [40], Sun and Meng [46], Chan } \\
\text { and Kumaraswamy [40], Assaf and Hejji } \\
\text { [12], Enshassi [18],Kazaz et al. [8], } \\
\text { O'Brien [10] }\end{array}$ \\
\hline & $\begin{array}{l}\text { Poor communication between } \\
\text { Parties }\end{array}$ & $\begin{array}{l}\text { Motawa, [40],Sun and Meng [43], Assaf } \\
\text { and Hejji [12], Enshassi [18], Doloi et } \\
\text { al.[49], Kazaz et al. [8] }\end{array}$ \\
\hline & $\begin{array}{l}\text { Owners Level of Construction } \\
\text { Sophistication }\end{array}$ & $\begin{array}{l}\text { Chan and Kumaraswamy [37], Assaf and } \\
\text { Al-Hejji[12], Enshassi [18], Ling et al.[57] }\end{array}$ \\
\hline \multirow{4}{*}{ 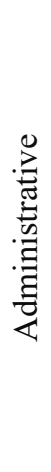 } & Poor Contract Management & $\begin{array}{l}\text { Hsieh et al.[38], Odeh and Battaineh [44], } \\
\text { Doloi et al.[49], Sha'ar et al.[47], Faridi } \\
\text { and El-Sayegh [58] }\end{array}$ \\
\hline & $\begin{array}{l}\text { Inappropriate choice of project } \\
\text { delivery system }\end{array}$ & $\begin{array}{l}\text { Assaf and Hejji [12], Doloi et al.[49],Ling } \\
\text { et al. [57], Sha'ar et al. [47] }\end{array}$ \\
\hline & $\begin{array}{l}\text { Inappropriate choice of contract } \\
\text { type }\end{array}$ & $\begin{array}{l}\text { Assaf and Hejji,[12],Sha'ar et al.[47], Ling } \\
\text { et al. [57] }\end{array}$ \\
\hline & $\begin{array}{l}\text { Low Contract Price (Competitive } \\
\text { Bidding) }\end{array}$ & $\begin{array}{l}\text { Arain and Pheng [20], Assaf and Hejji } \\
\text { [12], Sha'ar et al.[47], Doloi [59], Holt et } \\
\text { al.[60] }\end{array}$ \\
\hline
\end{tabular}


Table 1 - Change Factors and References (continue)

\begin{tabular}{|l|l|l|}
\hline \multirow{2}{*}{\begin{tabular}{|l|} 
Unforeseeable Natural Conditions \\
\cline { 2 - 2 }
\end{tabular}} & $\begin{array}{l}\text { Motawa [40], Hsieh et al.[38], Wu et al } \\
{[21], \text { Kazaz et al. [8],Sha'ar et al.[47], }} \\
\text { Enshassi [18] }\end{array}$ \\
\cline { 2 - 3 } & $\begin{array}{l}\text { Fluctuation in Tax / Interest Rate / } \\
\text { Material and Labor Cost }\end{array}$ & $\begin{array}{l}\text { Sun and Meng [43], Andersen et al. [61], } \\
\text { Love et al.[62], Doloi et al [49], Zaneldin, } \\
\text { [14], Enshassi [18] }\end{array}$ \\
\cline { 2 - 3 } & $\begin{array}{l}\text { Change in government laws/ } \\
\text { regulations }\end{array}$ & $\begin{array}{l}\text { Motawa [40], Hsieh et al. [38] ,Andersen } \\
\text { et al.[61], Assaf and Hejij [12], Doloi et al. } \\
\text { [49], Yap et al.[52], Enshassi [18] }\end{array}$ \\
\cline { 2 - 2 } & $\begin{array}{l}\text { Shortening / Compression in } \\
\text { Project Schedule }\end{array}$ & $\begin{array}{l}\text { Motawa [40], Sun and Meng [43], Chan } \\
\text { and Kumaraswamy [37], Odeh and } \\
\text { Battaineh [44], Enshassi [18] }\end{array}$ \\
\hline
\end{tabular}

\subsection{Categorization of Causes that result in Changes}

In this study, it was deemed appropriate to evaluate change factors within certain categories in order to obtain more focused results. In this respect, the change factors were evaluated in 5 different categories. In accordance with factor types, 5 different change categories were formed based on the validity of 18 different research studies in literature as shown in table 2. Change factors are placed in the relevant category according to factor types based on the literature. (See in Table 1). Definitions of change categories were presented as follow:

\subsubsection{Planning and Design Related Causes:}

Hsieh et al.[38] and Motawa [40], were defined that causes of changes are basically related to errors, omissions, and defects in design and planning, such as inconsistency between drawings and site conditions, mistaken quantity estimates, planning mistakes, citation of inadequate specifications, etc. In general, the design and planning team is responsible for changes caused by factors in this category [38]. Love et al. [63], were stated that documentation errors and omissions have resulted as a consequence of the lack of communication between client and design team members in the design phase of construction projects. It was reported that almost $75 \%$ of problems or rework on the construction projects were connected to the design phase [63].

In this respect, eight factors were included in the planning and design category (See in Table 1) which regarding design documents, design coordination and quantity estimates.

\subsubsection{Construction and Site Related Causes:}

Motawa [40] and Lee et al.[29], were demonstrated that change causes are generally related to construction execution process due to adopting new construction techniques / methods, site 
conditions, difficulties in labour, and difficulties in work execution and control methods. Location and underground conditions are becoming the main project-specific dynamics that affect the construction process [50,62, 64]. Frimpong et al. [65], were stated that the execution of the project is affected by inherent site conditions. Yap et al [66], were denoted that the unavailability of material and equipment in the market in execution may cause changes in projects.

Six factors were placed in construction and site category which associated with construction methods, site inspections and site conditions, resource availability and shop drawings in the construction process (See in Table 1).

\subsubsection{Human Factor Causes Changes:}

Motawa [40], was stated that knowledge and experience of the project team are the key components to undertake successful projects. The study denoted that, lack of effort of individuals and poor communication as a result of the cultural issues of organizations participating in the project may lead to changes. Hwang et al [67], were emphasized that "client-related rework" due to client and client's representatives are the main cause of rework in construction. "Replacement of materials by the client" and "change of plans or scope by the client" are reported as the highest frequent cause and contributed the most to client-related rework.

Three factors were placed in people category which, regarding the experience, effort, communication level and attitude of the parties involved in the construction project (See in Table $1)$.

\subsubsection{Administrative and Contract Related Causes:}

Akinsola et al. [22], were referred that different contract strategies and organizational structures, and management style, are the dynamics of the construction organization. The study was clarified that organization and administrative factors may lead to changes in projects such as the administrative method of procurement, type of contract, method of tendering, type of tender document used, bidding environment and percentage of the adequacy of design document before tender [22]. Arain and Pheng [11] and O'Brien [10], were stated that in the case of the low contract price in competitive bids. the contractor's desired profitability can be a potential cause of changes in construction projects by strive to convince the project owner to allow certain changes, leading to additional financial benefits for him.

In this regard, four factors were included in the administrative and contract category (See in Table 1) which, related to the quality and type of the contract, tendering method and bidding competitiveness.

\subsubsection{External Causes for Changes:}

Alaghbari et al. [68], were stated that economic conditions, law, and regulation are external factors that can lead to changes. Physical environmental conditions, economic policy, and socio-political conditions are considered as external factors of change causes [62]. Aiyetan et al [69], were referred that the external factors had the most effect on the project parameter as a consequence of 
the change of governmental regulation. Hsieh et al. [38], were reported that works in project may change by the effect of government rules/regulation government agencies.

Four change factors were included in the external category which, associated with the uncertain economic conditions, weather conditions, rules/regulations and decisions of authority (See in Table 1). These factors are basically related to the effects arising outside of the project and are not composed of the project's technical and administrative facilities and not related to the performance of the project and performance of the parties.

Categories of change factors and references were presented in table 2 as follow:

Table 2 - Categories of Changes and References.

\begin{tabular}{|c|l|}
\hline \multicolumn{1}{|c|}{ Groups } & \multicolumn{1}{c|}{ References } \\
\hline Planning and Design & $\begin{array}{l}\text { Motawa [40], Sun and Meng [43], Yap et al. [66], } \\
\text { Love et al [63],Chan and Kumaraswamy [37], }\end{array}$ \\
\hline Construction and Site & $\begin{array}{l}\text { Motawa [40], Lee et al.[29], Doloi, et al.[49], Sun and } \\
\text { Meng [43],Yap et al.[66], Love et al.[62], Mohamad et } \\
\text { al.[50],Hsieh et al.[38], Lo et al.[45], Kazaz et al.[8] }\end{array}$ \\
\hline Human Factors & $\begin{array}{l}\text { Motawa [40], Lo et al.[45], Doloi, et al.[49], Yap et } \\
\text { al.[66], Hwang et al.[67],Sun and Meng [43], Yap et } \\
\text { al.[52], Kazaz et al.[8], Sha'ar et al. [47], Enshassi et } \\
\text { al [18] }\end{array}$ \\
\hline Administrative & $\begin{array}{l}\text { Faridi and El-Sayegh [58], Akinsola et al.[22], Kazaz et } \\
\text { al.[8] }\end{array}$ \\
\hline External & $\begin{array}{l}\text { Motawa [40],Sun and Meng [43], Yap et al.[66], } \\
\text { Hsieh et al.[38],Yap et al.[52],Lo et al.[45], Sha'ar et } \\
\text { al.[47], Faridi and El-Sayegh [58], Enshassi et al [18] }\end{array}$ \\
\hline
\end{tabular}

\subsection{Demographic Information of the Correspondents}

In the following phase, change factors were examined based on a survey of professionals in the construction industry in North Cyprus, Turkey, and the U.S.A.

Civil engineers and architects were interviewed on behalf of their organizations in North Cyprus and Turkey and in the U.S.A. A participant was included in the survey for each organization in order to perform an organizational based assessment. Since they had participated on behalf of the organization, they were asked to evaluate the questionnaire based on the organization's experience. Survey document was sent as hardcopy to the organizations located in North Cyprus however; an electronic file of survey document has been sent to organizations located in Turkey and the U.S.A. by using an online survey tool. A total of 96 organizations have participated in the survey. The distribution of regions, organizations and participants' profiles were presented in Table 3. 
Investigation of Organizational and Regional Perceptions on the Changes in ...

Table 3 - Distribution of the Regions, Organizations and Participant Profile

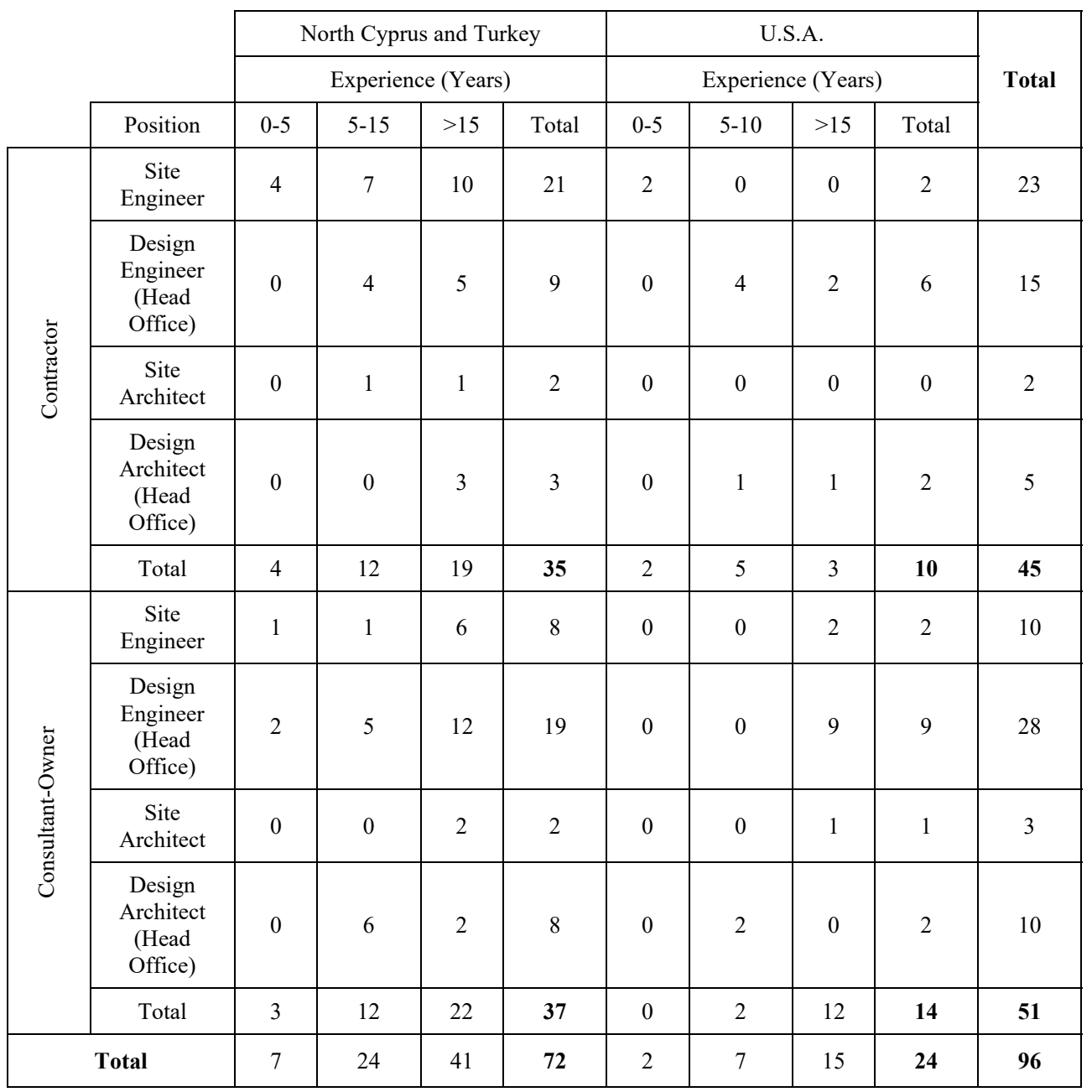

In this study, two different organizational and regional characteristics are discussed based on the factors of change. The first organization type was considered to be contractor who represents the party in which undertakes the implementation of the construction projects and as a result, the party that aims to achieve financial success. The second type of organization is together the consultant and the owner where both of them have authority to produce technical and administrative decisions in project phases and to supervise the contractors as well as to decide on the financial return in which the contractor is entitled. In this way, the number of contractors and consultant owners participating in the survey has been fairly balanced. 
On the other hand, the selected first region type is Northern Cyprus and Turkey together where both of them are similar characteristics and developing countries. The selected second region is the United States (U.S.A.), where has quite different characteristics and as representative of the developed countries. Northern Cyprus and Turkey were discussed together since they have similar however, the USA, which has different characteristics, is discussed as the second region type. Research findings were categorized and discussed in order to emphasize the impact of organizational and regional characteristics between organizations and region types. The data collection and the analysis methods were explained in the following section of the article.

\subsection{Importance Index Scores for Different Factors}

In the survey, change factors were assessed based on three parameters designated by the order as the frequency of occurrence, impact on cost and impact on time on the construction projects.

Participants have been asked to examine the change factors on the basis of lump-sum contracted and design bid build procured reinforced concrete building projects sized up to $5000 \mathrm{~m} 2$. Since this study was intended to make an organizational based assessment, the participants were asked to evaluate the change factors based on the experience of the organization rather than their personal experience.

Factors weighting method were chosen to obtain the opinions of participant's ideas through the survey. Five-point Likert scale were used in order to examine the change factors based on the frequency of occurrence, impact on cost and impact on time on the construction projects. The factor's level of significance was determined by calculating factors relative Importance Index scores (R.I.I.) based on the frequency of Occurrence (F.I.), impact on project cost (C.I.) and impact on project time (T.I.). Factors Relative Importance Index scores were calculated by using equation (1):

$$
\text { R.I.I. }(\%)=\frac{\sum W_{i} \times X_{i}}{A \times N}
$$

Where,

R.I.I. (\%): Relative Importance Index for Frequency of Occurrence (F.I.); Relative Importance Index for impact on project cost (C.I.); Relative Importance Index for impact on project time (T.I.).

Wi: The weight assigned on Likert's scale given to each factor by the respondents and ranges from 0 to 4, where; 0: Never, 1: Rare, 2: Moderate, 3: Frequent, 4: Very Frequent for Frequency of Occurrence; 0: No Effect, 1: Weak, 2: Moderate, 3: Strong, 4: Very Strong for impact on project cost and time; 0: No Effect, 1: Weak, 2: Moderate, 3: Strong, 4: Very Strong for impact on project time;

$\mathrm{X}_{\mathrm{i}}$ : Number of choice of the (i) th weight in the Likert's scale for the change factor.

A: is the highest weight (i.e. 4 in this case) and;

$\mathrm{N}$ : is the total number of respondents 


\subsubsection{Risk Significance Index of Change Factors}

The top risky change factors were identified depending on the outcome of the frequency, cost and time indexes. For this, the levels of risk of change factors were determined by calculating the Risk Significance index (R.S.I.) scores. The factor that has the highest risk significance index (R.S.I.) was expressed as the riskiest factor. Factors Risk Significance Index (R.S.I.) scores were calculated by using frequency index as multiplier effect and aggregating, cost and time impact indexes (See equation 2 and 3).

$$
\text { AV..S.I. }(\%)=\frac{C . I+. T . I .}{2}
$$

Where;

AV.S.I. = Average Severity Index; C.I. = Cost Impact Index; T.I. = Time Impact Index

$$
\text { R.S.I. }(\%)=\frac{F . I . \times A V . S . I .}{100}
$$

Where; R.S.I. $=$ Risk Significance Index; F.I. $=$ Frequency Index; AV.S.I. $=$ Average Severity Index (equation 2)

\subsubsection{Risk Significance Index of Change Categories}

The risk significance index for change categories (Av. R.S.I.) was calculated by calculating the average of the risk importance index (Av. R.S.I.) of factors within the category (See equation 4).

$$
\text { Av.R.S.I. }(\%)=\frac{\sum_{i=1}^{n} \text { R.S.I. }}{n}
$$

Where;

AV.R.S.I. $=$ Risk Significance Index of change category; R.S.I. $=$ Risk significance index of the

(i) th factor in change category; $n=$ Number of factors in the change category.

\section{RESEARCH FINDINGS AND DISCUSSION}

The research findings were presented and discussed according to the types of organizations and regions.

\subsection{Top Risky Change Factors according to the Different Organizational Characteristics}

Risk Significance Index (R.S.I.) of change factors according to organization types were presented in Table 4. According to the contractors, the top risky changes were comprised due to poor quality 
of the contract drawings. This finding has indicated that the most frequent most severe changes according to contractors were originated due to errors and poor quality in project drawings. The project owners have major responsibility for drawing documents since the preparation of project drawings is carried out by consultants under the owner's responsibility in design-bid-build procured projects. In this context, contractors have made effort to state that there is a lack of responsibility for the project owners and consultants as project drawing documents are issued under the responsibility of the owners and consultants.

On the other hand, "Low contract price due to competition" was specified as the most risky change factor according to consultants and owners which means, most frequent and severe factor on cost and time overruns. Consultants and owners interpreted that top risky changes occurred due to the low bid price associated with the contractor selection method. There are more chance to cost/time overruns when the bidding environment is highly competitive [11].

It has been observed that the likelihood of a tendency of cost and time overruns increases when contractors have a strong desire to get awarded as a result of keeping their costs below other bidders.

Adding or omitting of work items related to circumstances of the construction execution process and poor scope definition were ranked the second-highest risky change factor according to both organization characteristics. Adding or omitting items may be requested by any party due to many reasons. In fact, this can be a consequence of the side effects of many factors. Both quality of the design, as well as the comprehensiveness of other project documents as well as the level of organization and communication, may generate the consequence of adding extra work items. The contractor's desired profitability can be a potential cause of changes in construction projects. Addition of work items could be used as a means of achieving extra income. In this respect, additional works could be interpreted as a common source for the contractors to be able to achieve desired profitability since contractors may in efforts to include additional works in order to achieve financial benefits [10]. This can be interpreted as the unethical behaviour of contractors to achieve the highest possible level of profit. Besides, poor scope definition is one of the major triggers that may cause additions of works during execution $[39,47]$. The addition of extra works items could be reduced by detailed project designing and scope definition together with the preparation of comprehensive project documents.

These findings were also pointed out that, consultants and owners have higher concerns about changes since risk index average was higher in consultants-owners than contractor (See table 4). The consultants have a great responsibility in case of any disruption caused by the changes and the disagreement between the parties. This finding could be interpreted that, consultants are experiencing great challenging in resolving problems regarding changes so that the project can progress smoothly. On the other hand, project owners may incur additional costs due to the need for a financial source for the change.

According to these findings, potential measures were suggested in accordance with the organizational characteristics in the following section that aim to prevent top risky change factors were suggested in accordance with the organizational characteristics in the following section. 
Table 4 - Factors R.S.I. according to the organization types

\begin{tabular}{|c|c|c|c|c|c|}
\hline & \multirow{2}{*}{ Causes of Change } & \multicolumn{2}{|c|}{ Contractor } & \multicolumn{2}{|c|}{$\begin{array}{l}\text { Consultant - } \\
\text { Owner }\end{array}$} \\
\hline & & R.S.I. & Rank & R.S.I. & Rank \\
\hline \multirow{8}{*}{ 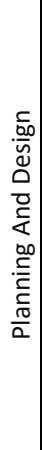 } & Errors/Inadequacies in Contract Drawings & 48.6 & 1 & 37.2 & 3 \\
\hline & Inconsistencies between different Designs & 34.7 & 3 & 34.7 & 4 \\
\hline & Errors and Inadequacy in Specification & 31.7 & 6 & 28.3 & 13 \\
\hline & Conflict among contract documents & 30.8 & 8 & 33.4 & 6 \\
\hline & Un-use of advanced design software & 24.2 & 16 & 18.7 & 21 \\
\hline & Constructability Ignored & 28.3 & 10 & 31.2 & 10 \\
\hline & Error in Cost Estimating and budgeting & 26.1 & 13 & 22.7 & 17 \\
\hline & Unrealistic imposed contract duration & 20.4 & 20 & 32.3 & 8 \\
\hline \multirow{6}{*}{ 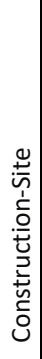 } & Inadequate site investigation in pre-construction & 30.2 & 9 & 31.6 & 9 \\
\hline & Uncertainties / problems of Subsurface & 22.7 & 17 & 25.8 & 14 \\
\hline & Provision of additional shop drawings & 31.0 & 7 & 29.7 & 12 \\
\hline & Errors in execution & 16.4 & 24 & 25.2 & 15 \\
\hline & Material / Equipment / Manpower shortage & 18.1 & 23 & 18.2 & 22 \\
\hline & Additions / Omissions of work items & 41.7 & 2 & 38.5 & 2 \\
\hline \multirow{3}{*}{$\begin{array}{l}\frac{0}{0} \\
\frac{0}{0} \\
\propto\end{array}$} & Lack of Experience of Project Participants & 32.3 & 5 & 33.5 & 5 \\
\hline & Poor communication between Parties & 28.0 & 12 & 33.3 & 7 \\
\hline & Owners Level of Construction Sophistication & 24.2 & 15 & 22.5 & 18 \\
\hline \multirow{4}{*}{ 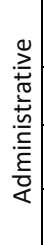 } & Poor Contract Management & 28.3 & 11 & 30.9 & 11 \\
\hline & Inappropriate choice of project delivery system & 22.2 & 18 & 22.7 & 19 \\
\hline & Inappropriate choice of contract type & 24.3 & 14 & 23.6 & 16 \\
\hline & Low Contract Price (Competitive Bidding) & 34.3 & 4 & 43.6 & 1 \\
\hline \multirow{4}{*}{ 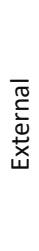 } & Unforeseeable Natural Conditions & 21.6 & 19 & 17.3 & 24 \\
\hline & $\begin{array}{l}\text { Fluctuation in Tax / Interest Rate / Material and Labor } \\
\text { Cost }\end{array}$ & 19.1 & 22 & 17.5 & 23 \\
\hline & Change in government laws/ regulations & 10.7 & 25 & 10.2 & 25 \\
\hline & Shortening / Compression in Project Schedule & 20.3 & 21 & 22.3 & 20 \\
\hline & Average R.S.I. (\%) & \multicolumn{2}{|r|}{26.80} & \multicolumn{2}{|r|}{27.40} \\
\hline
\end{tabular}




\subsubsection{Contractors' view on Change Causes}

Contractors stressed that the top risky changes are due to weaknesses and flaws in the project drawings. Contractors were in a struggle to express that they have no obligations and responsibilities regarding project designing since contractors are not involved in the design phase in design-bid-build procured projects $[11,56]$. In this context, contractors conclude that other major organizations such as owners and consultants are in charge of design-related issues. At this point, contractors are in an effort to state that they have right to claim additional payment and time as a result of changes which, originated from design issues since they express themselves as a victim in this case.

Globally standardized contract forms (i.e.: FIDIC) are used in construction projects [70]. However, there is no standard form and content for the drawings in the global sense. At this point, the contract drawings should be prepared based on specific standards in terms of structure, requirement, scope, and format that can be validated globally. With this structure and philosophy, the suffering and weakness caused by the drawings could be minimized $[15,70]$. Hereby, the drawing standard certification would be requested from the design firms. On the other hand, it would be beneficial to involve the contractors in the design process to take initiative for the design process in order to ensure the legalization of responsibilities all parties with respect to design documents. At this point, Design-Build procurement models could be effective to overcome this issue $[12,47]$. The integration of similar obligations in the Design-Build procurement method into the contracts could be effective to minimize design-related issues. In addition, high quality, broad participatory and comprehensive design process could also contribute to reducing the change necessity in the project.

In addition, factors' risk significance index score was quite to be higher in contractors' assessment compared to consultants-owners. These findings were interpreted that defects in the drawing may constitute a high risk for contractors than consultants and owners.

\subsubsection{Consultants and Owners View on Change Causes}

The top risky changes were originated due to the contractor's low bid price according to the consultants and owners. This finding was indicated that the low bidding price could have serious intense that precipitating change cases in construction projects.

Today, competitive and economic conditions are becoming more challenging. Generally, contractors may tend to offer a low bid price due to high competition to get awarded and to continue their activities [71].

Changes could be a major opportunity for contractors to be able to claim extra payments in order to reduce the distress of low bid prices [11]. The money and time claimed by the contractor for changes may be higher since competitive environment no longer present in the execution process. For this reason, contractors would tend to request changes in the purpose of increasing their earnings during the execution process [10,11]. Mohamad et al [50], emphasized that contractors may lead to design changes by offering to use available materials and alternative construction methods in the purpose of saving money and time. In this way, financial losses are tried to being reduced. Tan et al. [72] stated that contractors would tend to offer a lower bid price than those other competitors in a sacrifice of the profit margin and hence, financial damage may compensate by change orders during the execution process in order to claim extra financial resources from the 
owner [73]. It is believed and experienced that "low contract price due to competition" is highly risky for contractors as well, due to the reality that every change order of the contractor may not be awarded by owners. This issue could be able to defuse with the determination of base price offer as the tender threshold value in the purpose of not accepting any bid below of base price [12, 44]. The base price to be determined should also provide financial conditions to contractors to enable the project to be completed smoothly. In addition, it would be beneficial to evaluate bids by giving less weight to quantitative and more weight to qualitative criteria by applying qualitative based evaluation rather than quantitative-based for the contract awarding process.

At this point, bidding is becoming an important process to prevent forthcoming problems. For this reason, high-quality consultancy services are needed to be able to carry out the tender process in the most accurate way and to award the most accurate contractor for execution. This finding could interpret that, construction projects are subject to low quality of consultancy services. It will be beneficial for project owners to carry out their projects by experienced consultancy firms.

\subsection{Top Risky Change Categories on the basis of Organizational Characteristics}

Risk Significance index (R.S.I.) of change categories were presented in Table 5. The highest risk significance index was resulted in "Planning and Design" according to the contractors. In general, the activities in the "Planning and Design" phases are more concerned to the owner's obligations. Besides, this category has been resulted as one of the most risky category (second highest) by consultants and project owners. In this context, the greatest importance in project organizations should be given to the planning and design process. On the other hand, Consultant-Owner was emphasized that most risky change causes were originated due to administrative based issues which are more associated with the contract management and tendering process. The bottom line is that poor planning; design and administrative structure which are all regarding with preconstruction process can trigger changes significantly and therefore have a major impact on the cost and time of the project. These findings have pointed out that, obligations of organizations in the design and tendering processes have constitutes the greatest risks on construction projects. In addition, the risk index levels in both organization characteristics were fairly close in all categories except "external".

Table 5 - Risk Significance Index of Change Categories according to the organization types

\begin{tabular}{|l|r|r|r|r|}
\cline { 2 - 5 } \multicolumn{1}{c|}{} & \multicolumn{2}{l|}{ Contractor } & \multicolumn{2}{l|}{ Consultant-owner } \\
\hline Change Category & \multicolumn{1}{l|}{ Av. R.S.I. } & \multicolumn{1}{c|}{ Rank } & \multicolumn{1}{c|}{ Av. R.S.I. } & Rank \\
\hline Planning and Design & 30.6 & 1 & 29.81 & 2 \\
\hline Construction and Site & 26.7 & 4 & 28.17 & 4 \\
\hline People & 28.2 & 2 & 29.77 & 3 \\
\hline Administrative & 27.3 & 3 & 30.20 & 1 \\
\hline External & 17.9 & 5 & 16.83 & 5 \\
\hline Average & 26.10 & & 26.95 & \\
\hline
\end{tabular}




\subsection{Top Risky Change Factors according to the Different Countries and Regions}

The top risky change factors were examined according to the opinions of organizations located in different regions. In this context, the following results were categorized and discussed according to the regions of organizations.

\subsubsection{North Cyprus and Turkey}

R.S.I. of change causes according to the organizations in North Cyprus-Turkey was presented in table 6. "Low contract price due to competition" which associated with bidding evaluation and tendering process was identified as the most risky change factor according to the respondents in North Cyprus and Turkey. Generally, contractors in these regions are awarded based on prices. For this reason, quantification (price) based evaluation is mostly preferred rather than qualification, and therefore owners tend to award the lowest bidder contractors. In this context, contractors are in an effort to offer the lowest bid price in order to get awarded [71]. Construction projects face many difficulties due to the low bid price contracts, such as slow progress and quality degradations [9], hereby contractors may claim changes to compensate for financial loss due to low bid price $[10,11]$. Changes can be a potential opportunity for the contractor's desired profitability. Additional works due to changes could be a common source for the contractors to increase earnings [10]. Thereby, contractors' financial difficulties due to lower bid may be covered by additional payments due to changes.

Table 6 - Factors Risk Significance Index (R.S.I.) according to the Region Types

\begin{tabular}{|c|c|c|c|c|c|c|c|}
\hline & \multicolumn{7}{|c|}{ North Cyprus and Turkey } \\
\hline & \multirow[t]{2}{*}{ Causes of Change } & \multicolumn{2}{|l|}{ Contractor } & \multicolumn{2}{|c|}{$\begin{array}{l}\text { Consultant - } \\
\text { Owner }\end{array}$} & \multicolumn{2}{|l|}{ Total } \\
\hline & & R.S.I. & Rank & R.S.I. & Rank & R.S.I. & Rank \\
\hline \multirow{8}{*}{ 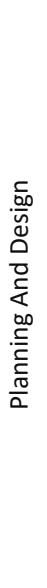 } & Errors in Contract Drawings & 49.9 & 1 & 37.8 & 3 & 43.1 & 2 \\
\hline & $\begin{array}{l}\text { Inconsistencies between } \\
\text { different Designs }\end{array}$ & 36.3 & 5 & 29.2 & 11 & 32.2 & 6 \\
\hline & $\begin{array}{l}\text { Errors and Inadequacy in } \\
\text { Specification }\end{array}$ & 32.2 & 7 & 29.2 & 12 & 30.5 & 10 \\
\hline & $\begin{array}{l}\text { Conflict among contract } \\
\text { documents }\end{array}$ & 32.2 & 6 & 36.8 & 4 & 34.6 & 5 \\
\hline & $\begin{array}{l}\text { Un-use of advanced design } \\
\text { software }\end{array}$ & 18.3 & 21 & 13.8 & 23 & 15.9 & 23 \\
\hline & Constructability Ignored & 25.6 & 13 & 33.9 & 6 & 29.8 & 11 \\
\hline & $\begin{array}{l}\text { Error in Cost Estimating and } \\
\text { budgeting }\end{array}$ & 26.1 & 12 & 22.2 & 19 & 23.9 & 17 \\
\hline & $\begin{array}{l}\text { Unrealistic imposed contract } \\
\text { duration }\end{array}$ & 21.3 & 18 & 33.2 & 8 & 27.3 & 13 \\
\hline
\end{tabular}


Investigation of Organizational and Regional Perceptions on the Changes in ...

Table 6 - Factors Risk Significance Index (R.S.I.) according to the Region Types (continue)

\begin{tabular}{|c|c|c|c|c|c|c|c|}
\hline & \multicolumn{7}{|c|}{ North Cyprus and Turkey } \\
\hline & \multirow[t]{2}{*}{ Causes of Change } & \multicolumn{2}{|l|}{ Contractor } & \multicolumn{2}{|c|}{$\begin{array}{l}\text { Consultant - } \\
\text { Owner }\end{array}$} & \multicolumn{2}{|l|}{ Total } \\
\hline & & R.S.I. & Rank & R.S.I. & Rank & R.S.I. & Rank \\
\hline \multirow{6}{*}{ 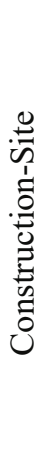 } & $\begin{array}{l}\text { Inadequate site investigation in } \\
\text { pre-construction }\end{array}$ & 31.6 & 10 & 32 & 10 & 31.8 & 9 \\
\hline & $\begin{array}{l}\text { Uncertainties / problems of } \\
\text { Subsurface }\end{array}$ & 23.8 & 14 & 28.3 & 13 & 26.5 & 14 \\
\hline & $\begin{array}{l}\text { Provision of additional shop } \\
\text { drawings }\end{array}$ & 32.1 & 8 & 25.6 & 16 & 28.5 & 12 \\
\hline & Errors in execution & 14.2 & 24 & 22.4 & 18 & 18.7 & 19 \\
\hline & $\begin{array}{l}\text { Material / Equipment / } \\
\text { Manpower shortage }\end{array}$ & 16.2 & 23 & 17.3 & 21 & 16.8 & 22 \\
\hline & Additions / Omissions of work & 39.1 & 3 & 33.6 & 7 & 35.9 & 4 \\
\hline \multirow{3}{*}{$\begin{array}{l}\frac{0}{2} \\
\frac{0}{0} \\
0\end{array}$} & $\begin{array}{l}\text { Lack of Experience of Project } \\
\text { Participants }\end{array}$ & 38.3 & 2 & 39.1 & 2 & 40.7 & 3 \\
\hline & $\begin{array}{l}\text { Poor communication between } \\
\text { Parties }\end{array}$ & 28.4 & 11 & 35.8 & 5 & 32.2 & 8 \\
\hline & $\begin{array}{l}\text { Owners Level of Construction } \\
\text { Sophistication }\end{array}$ & 21.3 & 19 & 24.2 & 17 & 22.9 & 18 \\
\hline \multirow{4}{*}{ 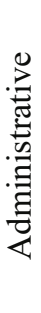 } & Poor Contract Management & 31.9 & 9 & 32.5 & 9 & 32.2 & 7 \\
\hline & $\begin{array}{l}\text { Inappropriate choice of project } \\
\text { delivery system }\end{array}$ & 22.2 & 16 & 27.1 & 14 & 24.8 & 16 \\
\hline & $\begin{array}{l}\text { Inappropriate choice of } \\
\text { contract type }\end{array}$ & 21.9 & 15 & 24.9 & 15 & 25.1 & 15 \\
\hline & $\begin{array}{l}\text { Low Contract Price } \\
\text { (Competitive Bidding) }\end{array}$ & 36.9 & 4 & 48.9 & 1 & 44 & 1 \\
\hline \multirow{4}{*}{ 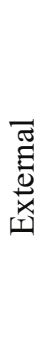 } & $\begin{array}{l}\text { Unforeseeable Natural } \\
\text { Conditions }\end{array}$ & 22.1 & 17 & 16.2 & 22 & 18.6 & 20 \\
\hline & $\begin{array}{l}\text { Changes in Tax / Interest Rate / } \\
\text { Material and Labor Cost }\end{array}$ & 19 & 20 & 13.4 & 24 & 15.9 & 24 \\
\hline & $\begin{array}{l}\text { Change in government laws/ } \\
\text { regulations }\end{array}$ & 10.7 & 25 & 11.2 & 25 & 11 & 25 \\
\hline & $\begin{array}{l}\text { Shortening / Compression in } \\
\text { Project Schedule }\end{array}$ & 17.4 & 22 & 18.3 & 20 & 17.9 & 21 \\
\hline \multicolumn{2}{|r|}{ Average R.S.I. (\%) } & \multicolumn{2}{|r|}{26.76} & \multicolumn{2}{|r|}{27.48} & \multicolumn{2}{|r|}{27.2} \\
\hline
\end{tabular}


Low prices can be more attractive to project owners in the short term. However, project owners may experience difficulties due to the tendency of contractors to increase incomes with additional works in the long term. At this point, potential forthcoming problems can be mitigated by choosing the most accurate contractor through a qualitative based evaluation method. In this regard, it is necessary to make legal arrangements to force on using a qualification based method in the tender process.

\subsubsection{Change Factors in the U.S.A.}

R.S.I. of change causes according to the respondents in the U.S.A. was presented in table 7. According to the participants in the USA, the riskiest changes are caused by "discrepancies between different designs". In this context, this has been stated that the conflict between project designs is the most common cause of changes in construction projects in the USA. These kinds of problems are encountered more particularly in large-scale projects. Today, the scale and the scope of the projects are in a growing trend. Multi-functional buildings are being built with an increasing global competitive environment trend. The compatibility and integrity between different designs are being more difficult due to the increase in project complexity. Nowadays the quality and function of the contract drawings gradually become more important with the growing trend of complex designs. In this regard, the consistency of different designs becomes one of the most significant factors influencing changes due to the implementation of large-scale, multifunctional and complex projects in the global construction industry today.

At this point, it is required to enhance and develop compatibility and integrity in a project to overcome conflicts between different designs. Different designs need to be combined in one holistic design to ensure integrity. In addition, it is necessary to create an environment in which different design units can work together. For this purpose, a holistic project design unit needs to be established in the design phase of the construction project. In this regard, different design units will better be managed through holistic project design unit. It is possible to reduce such problems

Table 7 - Factors R.S.I. according to the organization Types

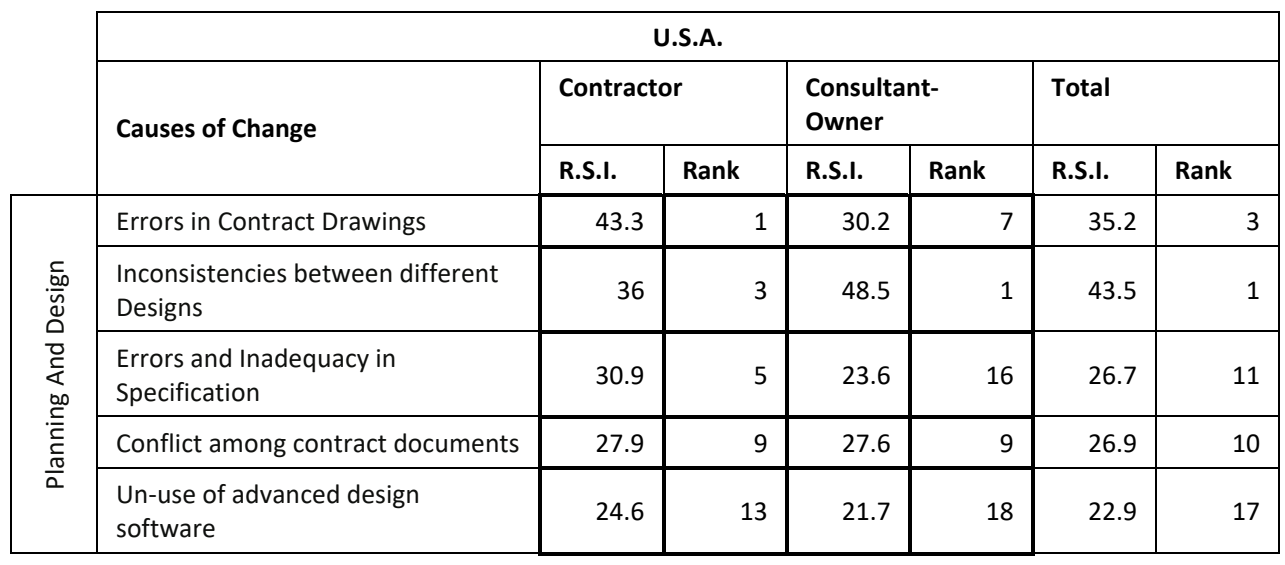


Investigation of Organizational and Regional Perceptions on the Changes in ...

Table 7 - Factors R.S.I. according to the organization Types (continue)

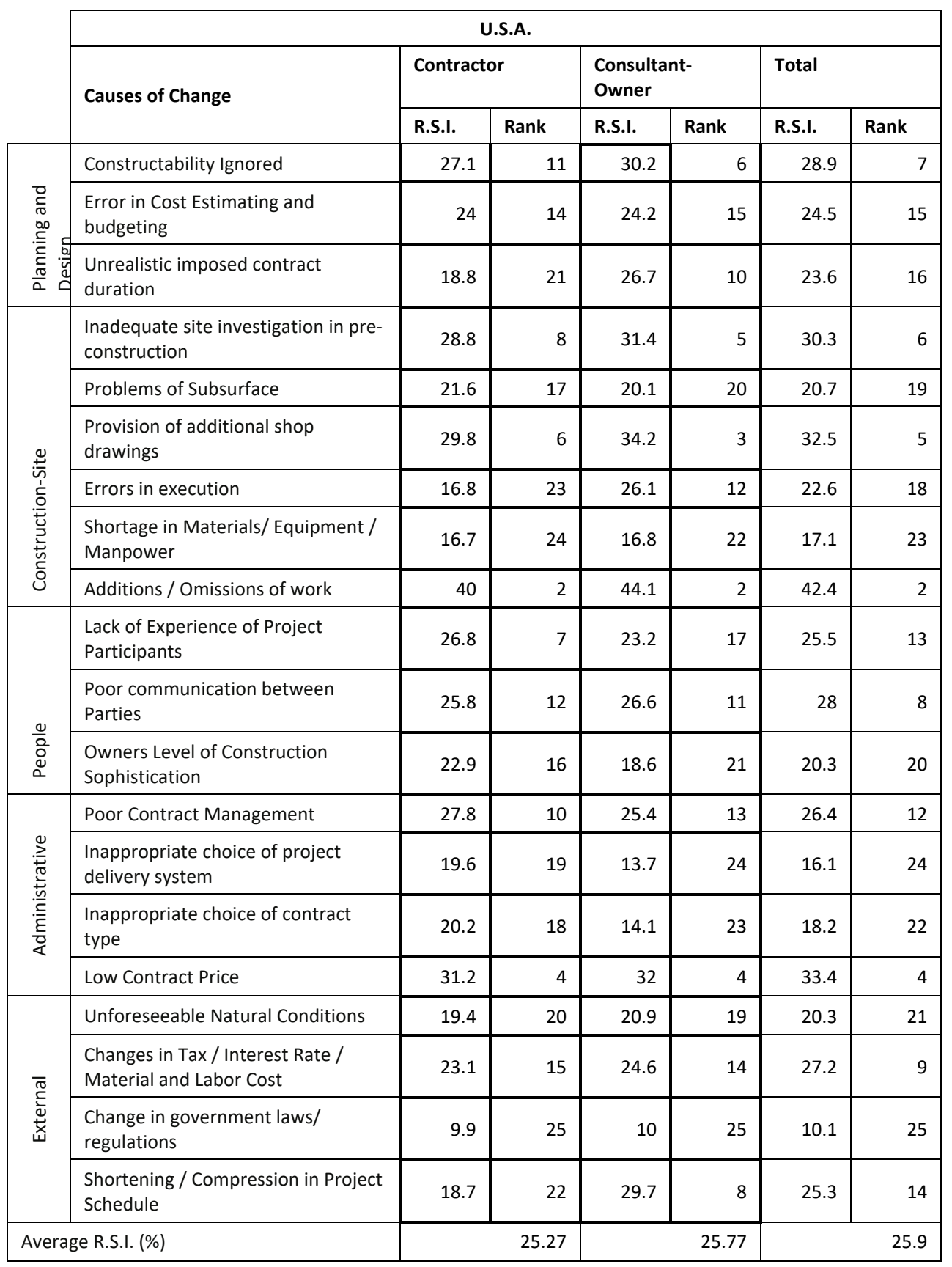


with BIM technology [34]. Today, the use of BIM in the United States is widely applied to ensure the compatibility between different project disciplines for construction projects. [74]. Different designs can be integrated easily and effectively by BIM tools. In addition, BIM tool ensures to integrate managerial information to the project design, so BIM is a powerful and effective method to enhance integrity in different design disciplines to overcome such problems in the construction industry. In this regard, it is necessary to make legal arrangements to enforce the use of the BIM tool in construction projects.

\subsubsection{Contractor's Perception according to the Different Regions}

Changes due to the weakness in drawings lead to the greatest risk according to the contractors in North Cyprus-Turkey and the U.S.A. In addition, these factors are constituted greater risk in Northern Cyprus and Turkey since the risk index score is much higher than in the U.S.A.

On the other hand, lack of experience of organizations and people involved in construction projects lead to one of the most risky changes in construction projects according to the contactors located in North Cyprus and Turkey, however, this factor has been stated to constitute a lower risk according to the contractors located in the U.S.A. Besides, changes that originated due to additions/omissions of work items were constituted almost the same risk level for contractors located both in North Cyprus-Turkey and the U.S.A.

\subsubsection{Consultant's and Owner's Perception according to the Different Regions}

The low bid price was leaded to the most risky changes according to the consultants and owners in North Cyprus-Turkey while it was emphasized to be much less risky according to the consultants and owner's in the U.S.A.

On the other hand, changes originated due to the inconsistencies between different designs that have constitutes the greatest risk in the U.S.A., while this was emphasized as to be much less risky for consultants and owners located in North Cyprus and Turkey.

\subsection{Top Risky Change Categories on the basis of Regional Characteristics}

R.S.I. of change categories according to the organizations in North Cyprus-Turkey and the U.S.A. were presented in tables 8 and 9 respectively.

\subsubsection{Discussion}

Most risky changes were caused due to the "Human" related factors according to the respondents in North Cyprus and Turkey whereas; this category has been stated to constitute a relatively low risk in the U.S.A because of the low R.S.I. On the other hand, changes composed due to the "Planning and Design" issues have been observed to create the same risk level in both regions since the risk index level is the same (See in table 8 and 9).

These findings show that the problem due to profile and performance of people involved in the project and project administrative status were indicated as source of very high risks in North 
Cyprus and Turkey, while problems due to the design and construction execution phase has been observed as source of the greatest risky in the U.S.A. In this context, the main defects in North Cyprus and Turkey were mostly related to human and administrative defects, whereas it was observed that the main flaw in the US is mostly technical based.

Table 8 - R.S.I. of Change Categories according to North Cyprus-Turkey

\begin{tabular}{|l|r|r|l|r|r|r|}
\cline { 2 - 8 } \multicolumn{1}{c|}{} & \multicolumn{9}{l}{ North Cyprus and Turkey } \\
\cline { 2 - 8 } \multicolumn{1}{c|}{} & \multicolumn{2}{l|}{ Contractor } & \multicolumn{2}{l|}{$\begin{array}{l}\text { Consultant- } \\
\text { Owner }\end{array}$} & \multicolumn{2}{l|}{ Overall } \\
\hline Factor Group & $\begin{array}{l}\text { Av. } \\
\text { R.S.I. }\end{array}$ & Rank & $\begin{array}{l}\text { Av. } \\
\text { R.S.I. }\end{array}$ & Rank & $\begin{array}{l}\text { Av. } \\
\text { R.S.I. }\end{array}$ & Rank \\
\hline $\begin{array}{l}\text { Planning and } \\
\text { Design }\end{array}$ & 30.24 & 1 & 29.51 & 2 & 29.66 & 3 \\
\hline $\begin{array}{l}\text { Construction } \\
\text { and Site }\end{array}$ & 26.17 & 4 & 26.53 & 4 & 26.37 & 4 \\
\hline People & 29.33 & 2 & 33.03 & 3 & 31.33 & 1 \\
\hline Administrative & 28.23 & 3 & 33.35 & 1 & 31.23 & 2 \\
\hline External & 17.30 & 5 & 14.78 & 5 & 15.85 & 5 \\
\hline Average & 26.25 & & 27.44 & 26.89 \\
\hline
\end{tabular}

Table 9 - R.S.I. of Categories according to the U.S.A

\begin{tabular}{|l|r|r|l|r|l|r|}
\cline { 2 - 8 } \multicolumn{1}{c|}{} & \multicolumn{6}{c|}{ U.S.A. } \\
\cline { 2 - 8 } \multicolumn{1}{c|}{} & \multicolumn{6}{|c|}{ Contractor } \\
\multicolumn{1}{c|}{$\begin{array}{l}\text { Consultant- } \\
\text { Owner }\end{array}$} & \multicolumn{2}{l|}{ Total } \\
\hline Factor Group & $\begin{array}{l}\text { Av. } \\
\text { R.S.I. }\end{array}$ & Rank & $\begin{array}{l}\text { Av. } \\
\text { R.S.I. }\end{array}$ & Rank & $\begin{array}{l}\text { Av. } \\
\text { R.S.I. }\end{array}$ & Rank \\
\hline $\begin{array}{l}\text { Planning and } \\
\text { Design }\end{array}$ & 29.08 & 1 & 29.09 & 1 & 29.03 & 1 \\
\hline $\begin{array}{l}\text { Construction } \\
\text { and Site }\end{array}$ & 25.62 & 2 & 28.78 & 2 & 27.60 & 2 \\
\hline People & 25.17 & 3 & 22.80 & 3 & 24.27 & 3 \\
\hline Administrative & 24.70 & 4 & 21.30 & 4 & 23.20 & 4 \\
\hline External & 17.78 & 5 & 21.30 & 5 & 20.73 & 5 \\
\hline Average & 24.47 & & 24.65 & 24.96 \\
\hline
\end{tabular}




\subsubsection{Discussion based on Contractors in Different Regions}

Most risky changes were composed due to issues in planning and design activities according to the contractors located in both regions. Contractors were also emphasized that changes originated due to the influence of the people involved in the project were constituted greater risk in North Cyprus-Turkey than the U.S.A.

On the other hand, contractors in the U.S.A. have been observed to be less concerned with respect to change risks since risk index score is rather low compared to contractors in North Cyprus and Turkey in all categories.

\subsubsection{Discussion based on Consultant-Owner in Different Regions}

Changes due to the administrative defects were composed more risk in construction projects according to the consultants and owners located in North Cyprus and Turkey; however, this was stated to be as much less risk for consultants and owners in the USA since risk index score was fairly low in the U.S.A.

On the other hand, changes due to planning and design flaws were constituted the same risk level for consultants and owners located in North Cyprus-Turkey and the U.S.A. In addition, changes due to administrative defects are constituted of greater risk according to contractors compared to the consultants and owners located in the U.S.A.

It is known that such changes causing both cost and time overruns and this leads to serious disagreements and disputes among parties involved in construction projects. In this regard, organizations may show a stance towards their interests while stating the reason for changes. Organizations might be in an effort to be insistent that counter organizations be responsible for changes. Results obtained in the study confirm this idea. According to results, it was observed that contactors, consultants and project owners have basically headed to point out to those change factors where they subject to less responsibility.

In general, most risky changes were emphasized to be composed due to design based issues according to the contractors however; most risky changes were resulted due to the low contact price according to the consultants and owners. In general, consultants and owners have major responsibility with respect to documents of drawing while; the bid price is more relevant to the responsibilities of the contractor's organizations.

On the other hand, it has been observed that the characteristics of the regions have a significant effect when interpreting the most risky change factors. The findings showed that the top risky change factor was identified as coherent in accordance with the regional characteristics. In North Cyprus and Turkey, "Low contract price" were designated as to be riskiest change factor, whereas "Inconsistency between different design" were identified in the U.S.A. In general, organizations located in North Cyprus and Turkey are preferred to carry out the project by achieving the lowest cost rather than high quality. This is because; more importance is given to cost not a quality while selecting contractors in North Cyprus and Turkey. This finding could be interpreted that shortterm success is more attractive than long-term for organizations in North Cyprus and Turkey. On the other hand, the biggest difficulties encountered in the U.S.A. are related to inconsistency between different design disciplines. Today, the most common technical challenge in construction 
projects is to be an incompatibility between project disciplines due to the need for large-scale, multi-functional and complex projects in the global construction sector.

All sectors in North Cyprus are suffered from weaknesses in institutionalization and comprehensiveness. This is due to the lack of global integrity of sectors in North Cyprus as a result of the implementation of global isolation by the international community. The isolation of North Cyprus from a global trend could be attributed to this fact. Lack of integrated to global standards leads to differences in tender laws in Northern Cyprus. The way of projects are carried out is different in Northern Cyprus; this is because the administrative and technical obligations of the projects differ according to global standards. This creates differences in perception and qualities in North Cyprus organizations compared to international organizations. In this regard, great importance should be given to the concept of institutionalization and this structure needs to be developed and implemented throughout the whole project phases.

\section{CONCLUSION}

A lot of changes are experienced in construction projects carried out in North Cyprus and Turkey. The reason for so many changes in construction projects is often the lack of quality consultancy services. The quantity-based selection method is often applied in North Cyprus and Turkey and thus, poor quality of consultancy services are provided due to the fact that the technical consultants are selected based on bid price (Quantity based) rather than quality based. This fact is very effective in this regard since the quality of the project outcomes (from design to execution) is subject to the efforts of consultancy services. Nowadays, the U.S.A. as a developed country is in trend in choosing consultants by applying a quality-based selection method. In this regard, project owners in North Cyprus and Turkey should assign the consultants by applying quality based evaluation rather than quantity. Project performances are affected dramatically as a consequence of project changes and claims and thus, any organization involved in the project may be condemned to pay the cost of changes. As general terms, the findings were pointed out that, the better preparation of project documents and comprehensive organization in terms of both technical and managerial aspects prior to construction execution may significantly help to reduce change necessity and will definitely more accomplished project will be terminated. The findings in this paper has only been proved according to the ideas of the construction organizations in North Cyprus, Turkey and the U.S.A. for lump sum contracted design bid build procured building projects because of the chosen region and project characteristics. Therefore, researchers are encouraged to examine the risk level of change causes and to examine the effectiveness of change mitigation measures with respect to different regional and project characteristics.

\section{Symbols}

\section{AV. S.I. $\quad$ : Average of Cost and Time Overrun Index}

R.S.I. : Risk Significance Index

AV. R.S.I. : Average Risk Significance Index

C.I. $\quad$ : Cost Overrun Index

F.I. $\quad$ : Frequency Index 
I.I. : Importance Index

T.I. $\quad$ : Time Overrun Index

Wi : The weight assigned on Likert's scale given to each factor

$\mathrm{Xi} \quad$ : Number of choice of the ith weight in the Likert's scale for the change factor

\section{Acknowledgments}

Authors of this study would like to thank Organizations for their participation to survey and contributions.

\section{References}

[1] Ming, S., Sexton, M., Aouad, G., Fleming, A., Senaratne, S., Anumba, C., Industrial Report: Managing Changes in Construction Projects Retrieved, Bristol UWE: School of the Built and Natural Environment, Bristol UWE, 2004.

[2] Ibbs, W., Wong, C., Kwak, H., Project Change Management Systems, Journal of Management in Engineering, 17, (3), 159-165, 2001.

[3] Anees, M.M., Mohamed, H.E., Abdul Razek, M.E., Evaluation of change management efficiency of construction contractors, Housing and Building National Research Center, 9,(1), 77-85,2013

[4] Moselhi, O., Assem, I., El-Rayes, K., Change Orders Impact on Labor Productivity, Journal of Construction Engineering and Management, 131, (3), 354-359,2005.

[5] Alnuami, A.S., Taha, R.A., Al Mohsin, M., Al-Harthi, A.S., Causes, Effecrs, Benefits, and Remedies of Change Orders on Public Construction Projects in Oman, Journal of Construction Engineering and Management, 136, (5), 615-622, 2010.

[6] Serag, E., Oloufa, A., Malone, L., Radwan, E., Model for Quantifying the Impact of Change Orders on Project Cost for U.S. Roadwork Construction, Journal of Construction Engineering and Management, 136, (9), 1015-1027, 2010.

[7] Arditi, D. Akan, T.A., Gurdamak, S., Reasons for Delay in Public Projects in Turkey, Cosntruction Management and Economics, 3, (2), 171-181, 1985

[8] Kazaz, A., Ulubeyli, S., Tuncbilekli, N.A., Causes of Delay in Construction Projects in Turkey, Journal of Civil Engineering and Management, 18, (3), 426-435,2012.

[9] İlter, O., Çelik, T., The Effect of Project Variables on Cost and Time of Construction Projects, 5th international Project and Construction Management Conference (IPCMC2018), North Cyprus, 2018

[10] O’Brien, J.J., 1998, Construction Change Orders, New York, McGraw Hill

[11] Arain, F.M., Pheng, L.S., How Design Consultants Perceive Potential Causes of Variation Orders for Institutional Buildings in Singapore, Architectural Engineering and Design Management, 1, (3), 181-196, 2005a. 
[12] Assaf, S.A., Al-Hejji, S., Causes of Delay in Large Construction Projects, International Journal of Project Management, 24, (4), 349-357, 2006.

[13] Kaming, P.F., Olomolaiye, P.O., Holt, G.D., Harris, F.C., Factors Influencing Construction Time and Cost Overruns on High-Rise Projects in Indonesia, Construction Management and Economics, 15, (1), 83-94, 1997.

[14] Zaneldin, E.K., Construction Claims in United Arab Emirates: Types, Causes and Frequency, International Journal of Project Management, 24, (5), 453-459, 2006.

[15] Ijaola, I.A., Iyagba, R.O., A comparative Study of Causes of Change Orders in Public Construction Projects in Nigeria and Oman, Journal of Emerging Trends in Economics and Management Sciences, 3, (5), 495-501, 2012.

[16] Oladapo, A.A., A Quantitative Assessment of the Cost and Time Impact of Variation Orders on Construction Projects, Journal of Engineering Design and Technology, 5, (1), 35-48, 2007.

[17] Hassanein, A.A.G., Nemr, W.E., Claims Management in the Egyptian Industrial Construction Sector: A Contractor's Perspective, Engineering, Construction and Architectural Management, 15, (5), 456-469, 2007.

[18] Enshassi, A., Arain, F., Al-Raee, S., Causes of variation orders in construction projects in the Gaza Strip, Journal of Civil Engineering and Management, 16, (4), 540-551, 2010 .

[19] Stare, A., Reducing Negative Impact of Project Changes with risk and change management, Zagreb International Review of Economics \& Business, 14, (2), 71- 85, 2011

[20] Arain, F.M., Pheng, L.S., The Potential Effects of Variation Orders on Institutional Buildings Projects", Facilities, 23, (11), 496-510, $2005 \mathrm{~b}$.

[21] Wu, C., Hsieh, T., Cheng, W., Statistical Analysis of Causes for Design Change in Highway Construction on Taiwan, International Journal of Project Management, 23, (7), 554-563, 2005.

[22] Akinsola, A.O., Potts, K.F., Ndekugri, I., Harris, F.C., Identification and Evaluation of Factors Influencing Variations on Building Project Cost, International Journal of Project Management, 15, (4), 263-267, 1997.

[23] Lu, H., Issa,R.R.A., Extended production integration for construction: a loosely coupled project model for building construction. ASCE, Journal of Computing in Civil Engineering, 19, (1), 58-68, 2005

[24] Sönmez, M.., Dikmen, S.Ü., Akbıyıklı, R., Time - Cost Relationships for Superstructure Projects in Turkey, Teknik Dergi, 31, (2), 03-01, 2020

[25] Ahbab, C.., Daneshvar, S., Çelik, T., Cost and Time Management Efficiency Assessment for Large Road Projects Using Data Envelopment Analysis, Teknik Dergi, 30, (2), $8937-8959,2019$ 
[26] Hanna, A.S., Camlic, R., Peterson, P.A., Nordheim, E.V., Quantitative Definition of Project Impacted by Change Orders, Journal of Construction Engineering and Management, 128, (1), 57-64, 2002.

[27] Hanna, A.W., Gunduz, M., Impact of Change Orders on Small Labor-Intensive Projects, Journal of Construction Engineering and Management, 130, (5), 726-733, 2004.

[28] Wambeke, B.W., Hsiang, S., Liu, M., Causes of Variation in Construction Project Task Starting Times and Duration, Journal of Construction Engineering and Management, 137, (9), 663-677, 2011.

[29] Lee, S., Tae, S., Jee, N., Shin, S., LDA-Based Model for Measuring Impact of Change Orders in Apartment Projects and Its Application for Pre Risk Assessment and Post Evaluation, Journal of Construction Engineering and Management, 141, (7), 0401501, 2015.

[30] Diekman, J., Nelson, M., Construction Claims: Frequency and Severity, Journal of Construction Engineering and Management, 111, (1), 74-81,1985

[31] Bröchner, J., Badenfelt, U., Changes and Change Management in Construction and IT Projects, Automation in Construction, 20, (7), 767-775, 2011

[32] Bakr, G.A., Studying the Status of Variations in Construction Contract in Jordan, Computing in Civil and Building Engineering, 187-194, 2014.

[33] Kocaman, E.., Kuru, M., Çalış, G., Investigating the Effect of Tendering Procedure and Contract Type on the Construction Contract Price, Teknik Dergi, 31, (1), 9789 - 9812 , 2020

[34] Oyewobi, L.O., Jimon, R., Olanrewaju, B., Shittu, A.A., Analysis of causes and impact of variation order on educational building projects, Journal of Facilities Management, $14,(2), 139-164,2016$

[35] Taylor, T.R.B., Uddin, M., Goodrum, P.M., McCoy, A., Shan Y., Change Orders and Lessons Learned: Knowledge from Statistical Analyses of Engineering Change Orders on Kentucky Highway Projects, Journal of Construction Engineering and Management, 138, (12), 1360-1369, 2012

[36] Dumont, P., Gibson, G.E., Fish, J., Scope Management using project definition rating index, Journal of Management in Engineering, 13, (5), 54-60,1997

[37] Chan, D.W.M. and Kumaraswamy, M.M., a comparative study of causes of time overruns in Hong Kong construction projects, International Journal of Project Management, 15, (1), 55-63,1997

[38] Hsieh, T., Lu, S., Wu, C.,Statistical Analysis of Causes for change orders in Metropolitan Public Works, International Journal of Project Management, 22, (8),679686,2004

[39] Memon, A.H., Rahman, I.A., Hasan, M.F.A.,Significant causes and effects of variation orders in construction projects, Research Journal of Applied Sciences, 7, (21),44944502, 2014 
[40] Motawa, I.A.,A systematic approach to modelling change processes in construction projects, The Australian Journal of Construction Economics and Building, 5,(1), 2005

[41] Love, P.E.,Edwards, D.J., Zahir,I.,Forensic project management: An exploratory examination of the causal behavior of design-induced rework, IEEE Transportation Engineering Management, 55,(2), 234-247,2008

[42] Chen,J.L.,KNN-based knowledge sharing model for severe change order disputes in construction. Automation in Construction, 17,(6),773-779,2008

[43] Sun, M., Meng, X.,Taxonomy for change causes and effects in construction projects, International journal of Project Management, 27, (6),560-572,2009

[44] Odeh, A.M., Battaineh, H.T.,Causes of construction delay: traditional contracts, International Journal of Project Management, 20, (1), 67-73,2002

[45] Lo, T.Y., Fung, I.W.H., Tung, K.C.F, Construction Delays in Hong Kong Civil Engineering Projects, Journal of Construction Engineering and Management, 132, (6), 636-649,2006

[46] Rosenfeld,Y., Root-Cause Analysis of Construction-Cost Overruns, Journal of Construction Engineering and Management,140, (1), 4013039,2013

[47] Sha'ar, K.Z., Assaf, S.A., Bambang, T., Babsail, M. and Fattah, A.M.A.El., Designconstruction interface problems in large building construction projects, International Journal of Construction Management, 17,(3), 238-250, 2017

[48] Mansfield, N., Ugwu, O., Doran, T., Causes of delay and cost overruns in Nigerian construction projects. International Journal of Project Management 12, (4), 254260,1994

[49] Doloi, H., Sawhney, A., Iyer, K.C., Rentala, S.,Analysing factors affecting delays in Indian Contruction Projects, International Journal of project management,30, (4), 479489,2012

[50] M. Mohamad, M. Nekooie, and A. Al-Harthy, "Design changes in residential reinforced concrete buildings: The causes, sources, impacts and preventive measures," J. Constr. Dev. Ctries, 17, (2), 23-44, 2012

[51] Assaf, S.A., Al-Khalil, M. and Al-Hazmi, M., Causes of delay in large building construction projects. ASCE Journal of Management in Engineering, 11(2), 4550,1995

[52] Yap, J.B.Y., Abdul-Rahman, H., Wang, H.,Collaborative model: Managing design changes with reusable project experiences through project learning and effective communication, International Journal of Project Management, 35, (7), 1253-1271, 2017

[53] Cox, I. D., Morris, J., Rogerson, J. H., and Jared, G. E., A quantitative study of post contract award design changes in construction, Construction Management and Economics., 17,(4), 427-439,1999

[54] Cox, S. and Hamilton, A.,Architect's Job Book, 6th edn, Royal Institute of British Architects, London, RIBA Publications, 1995 
[55] Enshassi A., Lisk R., Sawalhi I. and Radwan I.,Contributors to construction delays in Palestine, The Journal of American institute of constructors, 27, (2), 45-53, 2003

[56] Arain, F.M., Assaf, S., Low, S.P.,Causes of Discrepancies between Design and Construction. Architectural Science Review 47, (3), 237-249, 2004

[57] Ling, F.Y.Y., Chan, S.L., Chong, E., Ee, L.P., Predicting Performance of design-Build and Design-Bid-Build Projects, Journal of Construction Engineering and Management, $30,(1), 75-83$,

[58] Faridi, A.S. and El-Sayeng,S.M.,Significant factors causing delay in the UAE construction industry, Construction Management and Economics, 24,(11),11671176,2006

[59] Doloi, H.,Analysis of pre-qualification criteria in contractor selection and their impacts on project success, Construction Management and Economics, 27, (12),12451263,2009

[60] Holt, G.D., Olomolaiye, P.O., Harris, F.C.,A review of contractor selection practice in the U.K. construction industry. Building and Environment 30, (4),553-561,1995

[61] Andersen, B., Olsson, N.O.E., Onsøyen, L.E., Spjelkavik, I.,Post project changes,: occurrence, causes, and countermeasures, International Journal of Project Business, 4, (2), 308-328,2011

[62] Love, P.E., Holt, G.D., Shen, L.Y., Li, H., Irani, Z.,Using systems dynamics to better understand change and rework in construction project management systems. International Journal of Project Management 20 (6), 425-436,2002

[63] P. E. D. Love, Z. Frani, and D. J. Edwards, "A rework reduction model for construction projects,” IEEE Trans. Eng. Manag., 51, (4), 426-440, 2004

[64] Sambasivan, M. and Soon, Y.W., Causes and effects of delays in Malaysian construction industry. International Journal of Project Management, 25, (5),517-26, 2007

[65] Frimpong, Y., Oluwoye, J. and Crawford, L., Causes of delay and cost overruns in construction of groundwater projects in a developing countries: Ghana as a case study. International Journal of Project Management, 21, (5), 321-6, 2003

[66] Yap, J.B.Y., Abdul-Rahman, H., Wang, C., A Conceptual Framework for Managing Design Changes in Building Construction, MATEC Web of Conferences 66, 00021, 2016

[67] Hwang, B.-G., Zhao, X., Do, T.H. Van,Influence of Trade-Level Coordination Problems on Project Productivity,Project Management Journal,45, (5), 5-14,2014

[68] Alaghbari, M.W, Razali A. Khadir, Salim Azizah, Ernawati., The significant factors causing delay of building construction projects in Malaysia. Journal of Engineering, Construction and Architectural Management,14, (2), 192-206, 2007

[69] A. Aiyetan, J. Smallwood, and W. Shakantu, "A systems thinking approach to eliminate delays on building construction projects in South Africa," Acta Structilia,18,(2),19-39, 2011 
[70] İlter, O., Çelik, T., Evaluation of Change Causes in Execution Process of Construction Projects, Project and Construction Management Conference, (PYYK 2016), Eskişehir, Turkey, 2016

[71] Drew, D., Skitmore, M., The effect of contract type and size on competitiveness in bidding, Construction Management and Economics, 15, (5), 469-489,1997

[72] Tan, Y., Shen, L., Khaled, A., Song S., An Examination of the Factors Affecting Contractor's Competition Strategy: a Hong Kong Study, International Journal of Project Organization Management, 1,(1), 4-23, 2008.

[73] Crowley, L.G., Hancher, D.E., Risk assessment of competitive procurement, Journal of Construction Management, 121, (2), 230-237, 1995

[74] Bryde, D., Broquetas, M.,Volm, J.M., Daneshvar, S., Çelik, T., The Project Benefits of Building Information Modelling (BIM), International Journal of Project Management, 31, (7), 971-980, 2013 